\title{
Populism in Indonesia and its Threats to Democracy
}

\author{
Abubakar Eby Hara \\ Dept. of International Relations and Center for Research in Social Sciences and Humanities (C-RiSSH) \\ University of Jember, Indonesia \\ ebyhara@gmail.com
}

\begin{abstract}
This paper discusses the emergence of populist movements in Indonesia and its influence on Indonesian democracy. As in some democratic countries, populism also becomes one of Indonesia's political traits. Although not exactly the same as the general models of populism in the West, Indonesian populist figures such as Joko Widodo and Prabowo Subianto have enough political appeal. Both use populist style in 2014 presidential election. Another less known populist movement is Islamic populism that has long historical roots and sticking to the 2017 Jakarta Gubernatorial election. In contrast to the extreme right and left populists in Europe and Latin America, the Indonesian populist tradition is new, not yet having a clear program and divided. In this context, populism has not threatened democracy even it can channel people direct interests. Nevertheless, in the long run the potential threat of populism to democracy cannot be underestimated primarily because of the authoritarianism tendency in populist figures to challenge democracy principles. Similarly, massive populist campaigns can strengthen the formation of group identity that disrupts the social relations in society.
\end{abstract}

Keywords-populism; Indonesia democracy; Jokowi; Prabowo; Islamic populism.

\section{I.INTRODUCTION}

Populism has become one of the most popular approaches to studying the politics and democracy of Indonesia in recent years. There are some writings that use populism as its approach. Mietzner's book on the presidential election reveals that both Joko Widodo and Prabowo used populism to win the 2014 Presidential election [1]. Similarly, Aspinall wrote about how Prabowo rose as a strong Presidential candidate using populism [2]. Then Vedi Hadiz wrote a book on the social and historical foundations of the rise of Islamic populism and how this populism fills the absence of leftist criticism of capitalism in Indonesia [3]. In line with Hadiz, Jati argued that Islamic populism grow in some Islamic states to liberate the Muslim community from economic imbalances and marginalization [4]. In addition, Luky Djani et. al writes about the emergence of populist movement under Joko Widodo (Jokowi) which were a coalition of the poor, populist leaders, civil society activists and the alliance of social security groups [5]. Jokowi started this populism appeal from his place of origin in Solo region then moved to Jakarta and later to national level. Some analysis in mass media also discusses about for example the emergence of right-wing populism in Indonesia [6].

Based on several studies on populism above, this paper attempts to examine some of the major variations of populism in Indonesia and its impact on the development of democracy. This paper argues that in some respects, populism is part of the positive dynamics of democracy because it becomes a direct channel of people's congestion by an oligarchic system, but it also argues that populism in the Indonesian political context has the potential to inhibit and even reverse development of Indonesia democracy. Of the three variants of populism that will be described in this paper that are Joko Widodo, Prabowo and Islamic populism, all three have the potential to disrupt democracy.

To discuss the above problem, this paper is divided into five parts. The first part is Introduction. The second part describes what populism and its variants are. The third part discusses populism in Indonesia with its own distinctive features. The fourth section explains the reason for this emerging populism and its possible development that can disrupt the process of political development and democracy. The last part is conclusion.

\section{POPULISM AND ITS VARIANTS}

There are various notions of populism. In essence, populism was born as a direct expression of people's distress and protest against an increasingly elitist and oligarchic system of representative democracy. The existing process of representative democracy is seen as often not represent the interests of ordinary people and tends to represent the interests of the elite oligarchy and the bureaucracy. Political parties also tend to be oligarchic and do not fulfill promises to their constituents. The populist movements therefore consider the elite as 'corrupt elite' and populism represents the voice of the real people ('pure people') 
[7]. In addition to this assumption, populism believes in the sovereignty of the people who are increasingly neglected in the political process. People are also seen as having similar spirit and homogenous, which often results in the exclusion of 'people' that is inconsistent with their views [8]. Populism is thus regarded as a way out which represents the voice of ordinary people and which often appears and strengthens along with the birth of a charismatic leader. The leaders are able to mobilize people supports by using effective communication styles close to the needs of the people.

There are at least three kinds of populism commonly spoken of. The first is radical left-wing populism that is mainly developed in Latin America. The second is radical right-wing populism in Europe and America. The third is the populism of Islamic parties that started from the Middle East and then flourished to Turkey and Indonesia. According to Mudde and Kaltwasser, the ideology of the populist movement is necessary but it is not a strongly formulated ideology such as liberalism, fascism and socialism [8]. There is even a tendency for the populist movement to borrow some of these ideologies in their activities. The following is a brief summary of these three groups of populist movements.

The left-wing radical populist movements that developed in Latin America raised popular power with anti-imperialist rhetoric and offered socialism as an alternative way. These movements later developed into political parties led by figures such as Hugo Chávez in Venezuela, Evo Morales in Bolivia and Daniel Ortega in Nicaragua [10]. They are often referred to as radical left groups because they view neoliberalism and market mechanisms as ideologies that have caused the poverty among laymen and therefore need to be replaced with new development models. These campaigns that combine populism and socialism succeeded in uniting the oppressed and marginalized people against the 'corrupt elite' [7]. They argue for the need for sovereignty to be returned to the people which were then realized by the establishment of 'constituent assembly'. The establishment of this body not only eroded the influence of previously ruling elites but hampered the opposition's ability to populist rule [7].

The right-wing radical populist parties that developed in Europe combined populism with the ideology of authoritarianism and nativism. Authoritarianism is symbolized by the appeal to the law and order especiallyin terms of the need to regulate immigrants who are flooding their countries.
Nativism claims the necessity of prioritizing native value and identity above the values of foreigners or non-native [7]. There are campaigns to drive out immigrants that threaten the identity and homogeneity of society. The populist movement in Europe was spearheaded by French politician JeanMarie Le Pen, who then followed in the Netherlands, Italy and England. He succeeded in transforming the French right-wing elite into a populist movement [10]. His populist movement accused the ruling elites of having destroyed the welfare state system by bringing immigrants into the system. He also denounced European integration as benefited only a handful of cosmopolitan elites at the height of power.

The populist movement also appeared in Asia on figures such as Joseph Estrada and Rogerte Duterte in the Philippines, Narendra Modi in India, Thaksin Sinawatra in Thailand and Joko Widodo in Indonesia. Prior to this in the Islamic countries emerged Imam Khomaini in Iran and the Muslim Brotherhood movement in the Middle East. Even Muslim figures considered terrorist leaders such as Osama bin Laden and Abu Bakar al Bagdadi were regarded as charismatic leaders who succeeded in mobilizing some Muslims supporter. These leaders with their main supporters succeeded in formulating simply and easily understood friends and enemies discourse.

\section{POPULISM IN INDONESIA}

Populism in Indonesia gets serious attention in line with the development of populism in various parts of the world. But in the case of Indonesia, there are variants of the mainstreams of left, right and Islamic populism expressed above. The social and political context in Indonesia greatly influences the emergence these variants. In Indonesia, for example, the perspectives of socialism and communism have been banned since the New Order era, so that the socialist and the Marxist analyzes are dimmed. Islamic political parties have also been banned since the New Order era so that Islamic thoughts about the future of the state and democracy were not openly discussed until the time of reform. Meanwhile, the legacy of oppressive new order political norms in solving problems regardless of the root of the problem is still often seen as the right solution in the eyes of some Indonesians.

Such conditions make the development of populism in Indonesia slightly different from that in Latin America. Left populism in Latin America has a clear agenda of ending American imperialism. They reject the dominance of the ideology of neoliberalism and pro-market capitalism, and instead promote socialism as an alternative. Indonesian populism, on 
the other hand, has no basis for such traditions. Although in some measure the populism supported by Prabowo denounced foreign ownership of Indonesian companies and wanted to raise the welfare of farmers, there have not been so far clear alternative program as offered in Latin America.

Departing from this context, unlike in Latin America and Europe, Indonesia has no extreme left and right populism. In contrast to Latin America where populism has evolved since the 1940s, leftist populism in Indonesia was interrupted by the New Order regime and cannot offer alternatives like in Venezuela. Populism in Indonesia is also not as extreme as the radical right-wing party in Europe although a tendency towards it also exists. The role of Islamic populism did not get much attention in discussion of populism above, but lately religion became a unifying tool for some Muslims in Indonesia to achieve certain political purposes.

Reflecting on the above description, at least today there are three kinds of populist movements that developed in Indonesia, which can be briefly referred to as Jokowi, Prabowo and Islamic Defenders Front (Front Pembela Islam- FPI) populism. Rather than viewing them as ideological movements, their populism is more appropriately seen as part of a political strategy to strengthen position and support in elections. These three populisms have the same characteristics in terms of their appeal to the people and in garnering supports. But in terms of defining who the oppressed people are and the issues raised, they are different from one and another.

The people in Jokowi populism, for example, are the administratively oppressed people who experience difficulties in their lives. Therefore, in the case of transformation to be made, Jokowi promised to improve the bureaucracy and to form a clean government. He emphasized bureaucratic reform to better serve the people and to work for the people. Populism programs offered by Jokowi are for example, free health and education programs. Jokowi is also identified with simplicity and closeness with the common people. His identification with the people is shown in his direct meetings with the people and a great deal of attention to the problems of the little people. In this context, Jokowi populism cannot be fully incorporated into left populism. According to Mietzner, Jokowi's populism is rather unique because he does not explicitly attack elite groups that are considered corrupt but instead try to make bureaucratic reform. He called this populism a technocratic populism [1].
In contrast to Jokowi's populism, the people in Prabowo's definition are oppressed community groups such as farmers and fishermen who have to be saved with affirmative programs. They are the 'real people' while the 'corrupt elites' are those considered to work with the cukongs and international companies to make profit in Indonesia. Despite carrying anti-foreign discourse, Prabowo was less successful than Jokowi in identifying himself with the ordinary people mainly because of his political background and because of the distance he actually created with the people. Prabowo presented himself as Sukarno who carried the voice of the people but at the same time he also appeared as a master with all the luxurious facilities he has. In the context of populist leaders, Prabowo failed to identify himself as a representative of ordinary people. This is in sharp contrast to Jokowi or Duterte in the Philippines, who come from and part of the common people.

Populism brought by FPI to some extent also used corrupt elite jargons that colluded with Chinese business people to dominate Indonesia. But the main appeal of the PFI is religious jargon to unite ummah against infidels. In the case of defeating Basuki Tjahaja Purnama, a Christian and Chinese minority and incumbent governor of Jakarta, in Jakarta Gubernatorial election, religious jargons were used massively. The FPI populist movement, however, did not succeed in becoming a strong party like the strengthening of the Baratiya Janata Party in India using the Hiduism jargon to win popular support and now succeed in power.

In some cases populism in Indonesia is close to the right populism in Europe but not as extreme as it is. Jokowi, to a certain degree, claims the need for a strong state against foreign threats but his definition of nationalism is not exclusive. In contrast, Prabowo's populism and to some extent populism of FPI seeks to combine authoritarianism and nativism as in Europe. In terms of authoritarianism, Prabowo for example wants to regulate the society to be more orderly. His followers idolized a firm and authoritative leader, and they considered Indonesia not yet ready for democracy. They also expect a more orderly system like the New Order. In terms nativism, Prabowo was considered to represent and defend indigenous groups against non-indigenous groups who control the economy. This view originated from Prabowo's political journey which is seen as defending indigenous groups although in reality this assumption is debatable.

The third type of populism in Indonesia that can be attributed to left populism is Islamic populism. 
Vedi Hadiz tried to see the rise of Islamic populism from their economic and political downsides in global competition and especially in Western hegemony [3]. According to him, the Muslim Brotherhood movement is one example of the rise of Islamic populism which later developed into influential parties in Egypt, Algeria, Palestine, Turkey and Indonesia. Islamic populism thus according to Hadiz should be traced to historical and sociological roots of Islamic decline [3]. This deterioration is also reflected in the form of terrorist movements in Afghanistan and Iraq.

Hadiz's explanation is interesting because it seeks to see the rise of populist Islamic movements and parties from sociological and economic aspects not primarily from aspects of Islamic teachings. He does not reject ethnic and religious influences in the mobilization of this movement, but this must be seen in a larger framework of resistance to Western imperialism. Furthermore, Hadiz considers that the presence of populist Islam fills the void of discourse and ideology movement of socialism in Indonesia which was banned during the New Order period.

But the extent to which Islamic populism is classified as left populism remains an important question. The Islamic populist movement in Indonesia is not uniform and it is actually difficult to see if they have an alternative ideology to the existing system offered to the public. Even religious teachings remain important in Islamic populism such as in the emergence of Hizb ut-Tahrir and in the mass protest movement against Basuki, the Jakarta Governor spearheaded by several Islamic organizations, especially FPI. In FPI case, it may be more appropriate if it is paralleled with the radical rightwing party in Europe. The aspect of authoritarianism in the right-wing populist movement, for example, is demonstrated by claims of exclusivity of religious interpretation and by campaigns to discipline Muslims to remain one-sided. The aspect of authoritarianism in the right-wing populist is also reflected by the strengthening of the ulama's authority associated with the virtues and privileges of their position in society. This is particularly relevant to FPI ulama who are claimed to be descendants of the Prophet. Confronting their views, will be considered against the privilege and special position of Ulama. Authoritarianism in religious view is followed by nativism which views the Chinese group as nonnative whose loyalty to the nation is considered weak. The latter group is seen as merely seeking to make economic gains by making coalition with corrupt elites.
Combined populism with authoritarianism and nativism has a strong appeal in a massive demonstration against Basuki. In addition to being mobilized for religious reasons, the people are also equipped with the assumption of oppression by corrupt elites who collude with foreigners from China. In the definition of FPI, the ummah is the people and their voices are considered people's voices to be heard directly as it was during the Soeharto era and even the courts must also be subject to the voice of the people. In this context, the success of Basuki, the Christian and Chinese Governor in building Jakarta, for PFI supporters is considered an anomaly because it differs from the assumption that the Indonesian Chinese are part of an elite group that always carries out a coalition to dominate the economy and economic resources.

In summary, populism in Indonesia is similar to populism elsewhere in terms of the attempts to show that there are 'pure people' against 'corrupt elite'. But in some ways the definition of who the pure people are and who the corrupt elite are, differs from one populist movement to another. Populism in Indonesia is also difficult to be grouped into two general populist frameworks of left and right populism. In addition, Islamic populism is not much talked about in many writings abroad. Islamic populism also has its own definition about people, which departs from the definition of a special ummah as pure people against the ruling kuffar. The next question to be discussed in the next section is on whether these kinds of populism will have negative impact on the development of democracy in Indonesia.

\section{IMPACT ON DEMOCRACY}

Democracy in Indonesia is still in the process of formation and institutionalization. Many argue that populism has a negative impact on the process of democratic development. This is for example relevant for the case of Basuki who was defeated in gubernatorial election by FPI massive populist movement. The movement even demanded Basuki jailed over the 'will of the people'. This populist movement was also seen to have a negative impact on the development towards the maturity of democracy in Indonesia, especially as it ignores the principle of equality in a democracy in which all citizens, including minorities, deserve to be leaders. If Basuki who had a very good performance as a Governor won the election, then Indonesia could be equated with the established democracy in the world.

In the view of populist democracy supporters, populism does not threaten democracy and is even one of the solutions to the elitist democracy. 
Populism in Indonesia has become one way for political parties, mass organizations and presidential candidates to gain popular support for defeating their political opponents. However, in the sense of political strategy, populism can hamper the process of democratic development in Indonesia. Particularly in the context of Indonesia's still-poorly institutionalized democratic system, the tendency of authoritarianism, the tyranny of the majority and the neglect of the basic principles of democracy such as equality and pluralism inherent in the populist movement can pose a threat to democracy. This tendency makes populism labeled as 'proto-totalitarian' that can replace the democracy system [8]. Moreover, the commodification of religion in the populist movement has become an effective means of mass mobilization but further hinders the development of democratic values and principles. Campaigns using religious sentiments to mobilize the masses have made the electoral competition unbalanced, although the elections themselves are conducted fairly and openly.

In addition, the identity construction process in populist movements in Indonesia needs attention. The same is actually also true of global concerns, including Western countries that have matured its democracy. However, in the context of Western countries, a well-established democratic corridor can prevent a negative tendency from the strengthening of the identity of the populist movement. In Indonesia, populist movements and massive negative campaigns in certain presidential elections have divided people, resulting in a prolonged hatred between one group and another. Such populist movements tend to be intolerant and racist to other groups who are considered not part of their self-concept of the people.

Of the three populist movements discussed here, they all have the potential to threaten democracy in Indonesia. Prabowo's populism, for example, contains potent authoritarianism. For most Prabowo supporters, the idea expressed is that Indonesia needs a firm leader to protect the country and to organize the multicultural Indonesians. In the previous presidential election, Prabowo was seen as a stern figure to deal with external threats to the sovereign territory of Indonesia primarily because of his military background. The worry about the return of authoritarianism, should Prabowo won the election was reflected in some academic writing. Mietzner, for example, said Indonesia's democracy was saved with the victory of Jokowi and the defeat of Prabowo [11].
In addition to Prabowo, Jokowi-style populism also needs to be observed. When he became President, Jokowi did not abandon his populist style. His simple language and his close affinities with the little people continue to be done. Several promised programs such as building infrastructure both on land and at sea are being implemented. He remains popular in the eyes of the people. Among the elite and parliamentarians, Jokowi also received support from several parties which previously opposed to him. In the Parliament, Jokowi can strengthen his coalition. This increasingly powerful position logically makes it easy for Jokowi to implement his policies including the less popular ones.

Although not as authoritarian as former populist Thai Prime Minister, Thaksin Sinawatra when in power, Jokowi shows a growing stance against his political opponents. Jokowi, for example, using the word 'beat' for those who are considered to threaten the unity of Indonesia. Likewise for some opposition groups, the government-proposed Law on Mass Organization contains some clausal that can be used to silence not only those that the state defines as antiPancasila but also opposition groups in society. Concerns about the misuse of the Law, as was the case with the anti-subversive Law during the New Order used to suppress freedom and silence dissidents, emerged among opposition and academic figures.

In addition to the two kinds of populism above, Islamic populism also has the potential to endanger democracy. The use of ethnic and religious sentiment in politics is certainly not a typical Indonesia. In India, the Barathia Janata party, for example, uses Hindu Ultra-nationalist sentiments that abandoned the platform of Indian pluralist democracy laid down by the founding fathers of the nation. The use of religious sentiments in Indonesia, although not as large as political party in India, was quite massive to displace political opponents. In order to defeat Basuki, the incumbent Christian-Chinese Jakarta governor in Jakarta gubernatorial election, religious sentiments was successfully intensified and manipulated by FPI to discredit and defeat Basuki.

The uses of ethnic and religious sentiments are a danger to democracy and to the Indonesia multicultural state. They contain racism and violate the principles of democracy concerning the equality in which people have equal rights to occupy public office. Moreover, the mobilization of the people's power has exceeded its limits when it became a kind of 'street court' against Basuki. Populism is often said to bring people's voices directly, and is generally 
more related to the appeal to pro-people programs. But when the voice of the people is mobilized to intimidate the court in the name of people voice, it has exceeded the boundaries of the Constitution which outlines the role of an independent judiciary to decide whether or not a person is guilty. The law in the established democratic regime is precisely introduced to prevent the negative excesses of populism, but in Indonesia the pressure of the masses makes the law subject to 'the will of the people'.

\section{CONCLUSION}

In addition to some other approaches such as democratization and political modernization, populism is among the approaches that can explain the development of politics and democracy in Indonesia. Populism can reveal the problems that arise from the increasingly elitist process of pluralist formalistic democracy in Indonesia. In the perspective of political modernization, Indonesian democracy has been viewed in a linear fashion as it evolves toward maturity marked by increasingly rational tendency of voters. This common view at the national level often forgets the dynamics in which populist sentiments can be manipulated. Populism can not only interrupt the process toward the democratic maturity, but also can end democracy as people are mobilized using ethnic and religious sentiments.

This brief paper, has sought to reveal the emergence of populism and how it can threaten the process of democracy in Indonesia. Populism has not developed to a strong movement in Indonesia because it is fragmented and used by various groups, political parties and presidential candidates to compete one and another. Nevertheless, it has the potential to threaten the process of democratic development in Indonesia. Of the three groups that use populism in this paper, all three have potential that can hamper the democratization process. The Jokowi, Prabowo and Islamist populism, all have potential authoritarianism that can halt freedom. Therefore, it is necessary to have a further study on the limit of populism in Indonesian democracy.

\section{ACKNOWLEDGMENT}

I would like to thank Dr. Agus Trihartono from C-RiSSH University of Jember for sharing many ideas in the early formation of this paper.

\section{References}

[1] M. Mietzner, Reinventing Asian Populism: Jokowi's Rise, Democracy, and Political Contestation in Indonesia, Policy Studies 72, Washington DC: East West Center, 2015.

[2] E. Aspinall, 'Oligarchic Populism Prabowo Subianto's Challenge to Indonesian Democracy', Indonesia, No. 99, pp. 1-28, 2015.

[3] V.R. Hadiz, Islamic Populism in Indonesia and the Middle East, Cambridge University Press, 2016.

[4] W.R. Jati, Trajectory of Political Islam in Indonesia, Journal of Indonesian Islam, Vol. 07, No 02, December 2013

[5] O. Tornquist, O. Tanjung, L. Djani, S. Tjandra, Dilemmas of Populist Transactionalism, Yogyakarta: Research Center for Politics and Government (PolGov),

[6] A. Hermawan, Commentary: Can Jokowi stem the tide of Islamic populism?, The Jakarta Post, Jakarta, October 25, 2017

[7] C. Mudde and C.R. Kaltwasser, Populism: A Very Short Introduction , New York: Oxford University Press, 2017.

[8] K. Abts and S. Rummens, Populism versus Democracy, Political Studies, Vol. 55, No. 2, 2007, pp. 405-424.

[9] G.S. Reis and S.M. Vieira. (2009). Left-Wing Populists in Latin America? An Analysis of the Chávez and Morales Governments. [Online]. Available: http://paperroom.ipsa.org/papers/paper_1080.pdf

[10] R. Eatwell, The Rebirth of Right-Wing Charisma? The Cases of Jean-Marie Le Pen and Vladimir Zhirinovsky. Totalitarian Movements and Political Religions, Volume 3, Issue 3, 2002.

[11] M. Mietzner, Indonesia’s 2014 Elections: How Jokowi Won and Democracy Survived. Journal of Democracy. Volume 25, Issue 4, pp. 111-125. 